\title{
THE RISE AND FALL OF THE RED FOX BENEATH THE APEX OF PALLISER'S TRIANGLE
}

\author{
JAMES K. FINLEY, 10232 Summerset Place, Sidney, BC V8L 4X2 \\ E-mail: jameskfinley@islandnet.com
}

At its Annual General Meeting, held in the Cypress Hills in 1997, Nature Saskatchewan unanimously passed a resolution recognizing "the beneficial role of the Great Plains Coyote (Canis latrans latrans) in maintaining a healthy prairie ecosystem, the negative ecological impact that the Red Fox has caused on the prairies, and including this basic ecosystem problem in its strategic plan of priority issues for action." 8

This call for action followed an article that I published in Blue Jay in 1996 concerning the Red Fox invasion that my family and I had witnessed during the latter half of the 1960s in westcentral Saskatchewan. ${ }^{1}$ Since Coyotes are the primary agent in limiting fox numbers on the prairies, ${ }^{10,13}$ it is my contention that the ecological damage can be reversed through management decisions aimed at maintaining a Coyote population sufficient to exclude Red Foxes. ${ }^{8}$ Anecdotal evidence indicates that Coyotes have been regaining control at the expense of the fox but since there are no general wildlife monitoring programs in place, the ecological consequences continue to unfold in a void of empirical evidence.

This article began as an exercise in 2003 to determine whether the
Christmas Mammal Counts (CMC) could fill that empirical void and throw some light on the relationship between fox and coyote populations and some of the prey species. At that time the surveys had "fallen on hard times" according to the co-editor of the Blue Jay (A. Leighton, pers. comm., July 29, 2003) and it was uncertain whether they would continue or have any value in monitoring wildlife populations. The co-editor asked me whether anyone had ever looked at the data to see whether it might shed some light on the relationship between foxes and coyotes. I suggested that the surveys had begun too late to document the initial changes, but volunteered to conduct a preliminary analysis of the data.

The CMC were concocted, in large part, due to the Red Fox invasion. The idea began with Wayne Harris and myself, somewhere between Stan Rowe's ecology lectures and our statistics course at the University of Saskatchewan, Saskatoon. We shared similar perspectives from our rural farming backgrounds, and spent time together hunting and birding in each other's home territories. Wayne's perspective was different than mine because his home was deeper within the aspen belt, and he did not recall a 
time before the fox invasion. Wayne was an avid birder who encouraged my participation in the Christmas Bird Counts, but I questioned their utility in the absence of data on mammalian predators. Thus, the first Christmas Mammal Count was organized in $1974,{ }^{5}$ but after participating in it, I found employment outside the province, and left him holding the bag, a responsibility he carried on for 27 years. ${ }^{4}$

Undertaking a marathon of counts over a vast area of Saskatchewan ( 294 counts in 36 localities). Wayne amassed a wealth of experience and data. ${ }^{6}$ Public participation in the surveys rose from 16 counts in 1974 to 105 counts in 2001, all of which he compiled in addition to the bird surveys. ${ }^{11}$ In his brief overviews, Wayne commented on the frequency of occurrence of five main species, which were usually Coyote, jackrabbit, fox, White-tailed deer, and Snowshoe Hare, but given the variable geographic coverage, snow conditions, and use of tracks as proxy indicators, he wasn't able to say much about population trends. Besides, the fox invasion began before the mammal counts were initiated, and much of the ecological change had already occurred. ${ }^{1,3}$

\section{Methods}

As a preliminary exercise, I examined three species - Coyote, jackrabbit and fox, recorded from localities within the

Table 1. Frequency of occurrence and abundance of coyotes, foxes and jackrabbits in Palliser's Triangle ${ }^{a}$ recorded on Christmas mammal counts in selected years between $1974-2001$.

\begin{tabular}{|c|c|c|c|c|c|}
\hline $\begin{array}{l}\text { Year } \\
\text { \# counts } \\
\text { \# km car }\end{array}$ & $\begin{array}{l}1974 \\
9 \\
1635\end{array}$ & $\begin{array}{l}1976 \\
20 \\
1602\end{array}$ & $\begin{array}{l}1984 \\
34 \\
4489\end{array}$ & $\begin{array}{l}1994 \\
33 \\
5260\end{array}$ & $\begin{array}{l}2001 \\
41 \\
8512\end{array}$ \\
\hline $\begin{array}{l}\text { Coyote frequency } \\
\text { \# } \\
\# / \text { count } \\
\# / 100 \mathrm{~km}\end{array}$ & $\begin{array}{c}67 \\
14 \\
1.5 \\
0.8\end{array}$ & $\begin{array}{l}75 \\
8 \\
0.4 \\
0.5\end{array}$ & $\begin{array}{l}65 \\
51 \\
1.5 \\
1\end{array}$ & $\begin{array}{l}79 \\
96 \\
2.9 \\
2\end{array}$ & $\begin{array}{l}90 \\
153 \\
3.7 \\
2\end{array}$ \\
\hline $\begin{array}{l}\text { Fox frequency } \\
\qquad \begin{array}{l}\# \\
\# / \text { count } \\
\# / 100 \mathrm{~km}\end{array}\end{array}$ & $\begin{array}{l}67 \\
7 \\
0.9 \\
0.4\end{array}$ & $\begin{array}{l}50 \\
5 \\
0.3 \\
0.3\end{array}$ & $\begin{array}{l}53 \\
8 \\
0.2 \\
0.2\end{array}$ & $\begin{array}{l}30 \\
3 \\
0.1 \\
0.06\end{array}$ & $\begin{array}{l}46 \\
7 \\
0.2 \\
0.08\end{array}$ \\
\hline $\begin{array}{c}\text { Jackrabbit frequency } \\
\# \\
\# / \text { count } \\
\# / 100 \mathrm{~km}\end{array}$ & $\begin{array}{l}88 \\
16 \\
2.0 \\
0.1\end{array}$ & $\begin{array}{l}55 \\
47 \\
2.4 \\
3\end{array}$ & $\begin{array}{l}85 \\
108 \\
3.2 \\
2\end{array}$ & $\begin{array}{l}64 \\
11 \\
0.3 \\
0.2\end{array}$ & $\begin{array}{l}66 \\
42 \\
1.0 \\
0.5\end{array}$ \\
\hline \multicolumn{6}{|c|}{$\begin{array}{l}\text { a The following localities were included in the analyses: Assiniboia, Bethune, } \\
\text { Biggar, Coronach, Craven, Crooked Lake, Duval, Duperow, Eastend, Elbow, } \\
\text { Endeavour, Estevan, Fenton, Ft. QuAppelle, Feudal, Gardiner Dam, Glamis, } \\
\text { Govenlock, Grasslands, Harris, Herbert, Indian Head, Kindersley, Kutawagan, } \\
\text { Last Mountain, Leader, Luseland, Matador, Moose Jaw, Nicolla Flats, Pike } \\
\text { Lake, Qu'Appelle Valley, Ravenscraig, Raymore, Regina, Saltcoats, Saskatoon, } \\
\text { Saskatchewan Landing, Scott, Shamrock, Skull Creek, Spring Valley, Swift } \\
\text { Current, St. Victor, Weyburn, White Bear, Wolseley, Wynyard. }\end{array}$} \\
\hline
\end{tabular}


Mixed prairie ecosystem, as well as a few sites within the Aspen Parkland Raymore, Kutawagan etc. - surveyed by Wayne (Table 1). The localities are shown on the maps that accompany the annual CMC results. I selected five years spaced roughly evenly over the decades, beginning with a couple of surveys near the beginning, one a decade later, in the mid 80 s and 90s, and ending with the last survey in 2001. I calculated frequency of occurrence based on all evidence (e.g. tracks and actual sightings). Abundance indices were calculated from actual sightings only, divided by the number of kilometres observers traveled by vehicle. (This is the simplest method, but future researchers could also factor in the number of $\mathrm{km}$ surveyed by foot).

\section{Results}

The statistic of two coyotes per 100 $\mathrm{km}$ in 2001 represents the efforts of many observers from 41 localities, who traveled $8512 \mathrm{~km}$ and saw 153 coyotes. The rate of encounter is similar to 1994 , but three or four times higher than in the 1970s. Evidently coyotes have increased in abundance in the last decade.
In the same localities, observers recorded only 7 foxes in 2001, 0.08 per $100 \mathrm{~km}$, or one for every $1250 \mathrm{~km}$ surveyed, about five times lower than the rate in 1974. Thus the trend in abundance of foxes is inversely proportional to the number of coyotes.

Wayne often commented on the scarcity of jackrabbits, especially during the last decade of surveys. In 2001, only 42 jackrabbits were seen on all 41 counts; one per $200 \mathrm{~km}$. In my youth, it would have been easy to flush that many from a willow-fringed slough! The density of jackrabbits doesn't show any clear trends across the decades; despite the reduction in foxes, their populations have not rebounded. This suggests that foxes are not responsible for keeping jackrabbit populations at low levels, or perhaps they are caught in a "predator sink" whereby the prey are unable to rise above normal predation pressures and other mortality factors.

In addition to the abundance indices, I examined frequency of occurrence of the Coyote, Red Fox, and Sharp-tailed

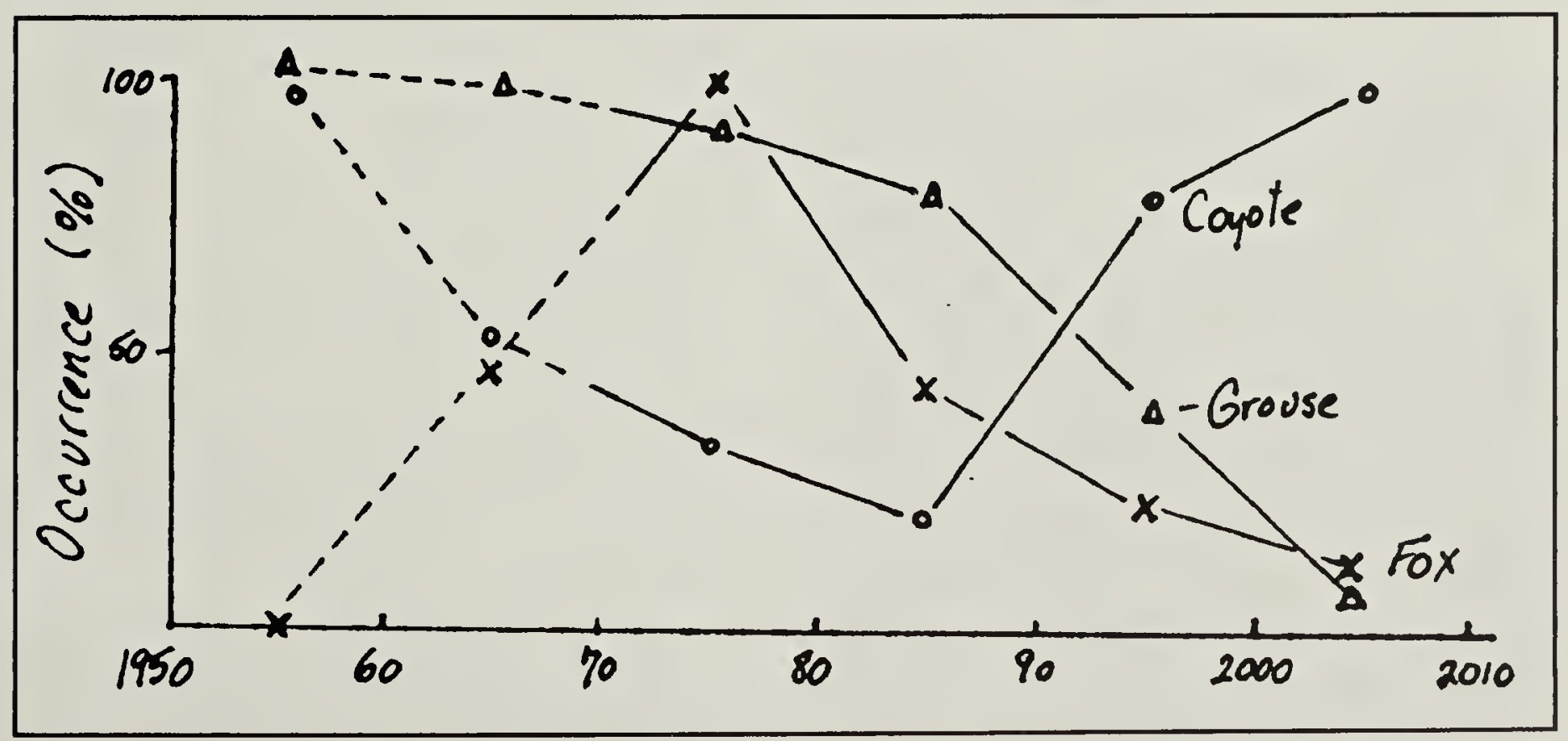

Figure 1. Occurrence by decade of Coyotes, Red Foxes and Sharp-tailed Grouse at Luseland, during the last half of the twentieth century. Based on Christmas counts (solid line) and local knowledge (dashed line). 
Grouse in counts at one locality, Luseland, that I know intimately (Figure 1). Figure 1 illustrates the essential outline of what I believe to be one of the most important ecological phenomena to have impacted the Canadian prairies in the last half of the twentieth century. ${ }^{2,3}$ It shows a reversal in fortunes of the top predator and the long-term decline and near extirpation of a prey species, the Sharp-tailed Grouse. As with the jackrabbit, failure of the Sharp-tailed Grouse to recover may indicate a threshold effect where it is unable to rise above other limiting factors, including hunting pressure, predators and habitat change.

\section{Discussion}

Except for anecdotal accounts, the Red Fox invasion of the northern Great Plains was not quantitatively documented by science, and its consequences have only been recognized in retrospect. ${ }^{1,7,10,12}$ This exercise illustrates the basic outline of a major ecological phenomenon - the rise and fall of the Red Fox - that has occurred in the last half century. The data, collected by volunteer naturalists, support the hypothesis that there is an inverse relation between coyote and red fox populations. This has important implications for wildlife management. ${ }^{7,8,10}$

This exercise is not meant to be definitive, only to show its potential. Much more can be done to improve the analyses. The exercise reveals the potential of naturalists to collect invaluable data on wildlife populations while enjoying a Christmas tradition. Table 1 represents only a small portion of this collective effort. Not only is it rich in biological meaning, but it also represents a wealth of goodwill and energy expenditure (in fat and fossil fuel) by a dedicated cadre of skilled naturalists. The 2001 count represented over $14,000 \mathrm{~km}$ driven, $800 \mathrm{~km}$ walked, and 1065 hours of field time by 912 observers. This effort is worth at least $\$ 26,000$ (assuming 35 cents/ km and roughly 2700 person hours at minimum wage). Consider too the many hours that Wayne invested in tallying the results, and one can appreciate that each statistic is a priceless artifact.

This exercise represents a step toward implementing an integrative, ecosystem-based monitoring program. As a baseline, beginning in this millennium (2001), the equation for the mixed-grass prairie ecosystem would include Coyotes $=2$, Red Foxes $=.08$ and Jackrabbits $=.5$, over a common denominator of $100 \mathrm{~km}$. Obviously it can be improved by including other key species, standardizing survey procedures and selecting localities with a long history of counts. In the long run, the index could prove useful in testing hypotheses, gauging the impacts of government policies, and setting goals. Only then might we be able to answer Nora Stewart's prescient question, "What is the balancing effect of the coyote on the red fox population?"12 As Stan Rowe advised "Endangered organisms per se cannot be preserved. Ecosystems of which organisms are interesting ingredients can, however, be preserved - as long as the Ecosphere of which they are parts continues to function in the old natural and healthy way. ... Unless natural ecological systems are preserved, the native flora and fauna will not be preserved."

Finally, this exercise draws attention to one of the most important ecological phenomena to have affected the prairies in the last half of the twentieth century. My children's generation does 
not comprehend that the occurrence of the Red Fox has changed in the prairie ecosystem in recent times, ${ }^{7}$ and that what they are experiencing is a residual effect of a cause that began long before they were born. This exercise, therefore, addresses Nature Saskatchewan's strategic plan of action, i.e. "to promote a greater understanding and appreciation of our natural heritage and the ecological processes around us", and specifically, to promote awareness that the Red Fox, as an invasive species, has the potential to cause widespread ecological damage on the prairies.

\section{Conclusion}

The rise of the Red Fox, five decades ago, was due to the creation of a vacant niche, brought about, ultimately, by the snowmobile revolution and decimation of the apex predator, the Coyote. The fall of the Red Fox, over the past two decades, is due to the rise of the coyote population, brought about by a combination of socio-economic circumstances (rural depopulation, fewer snowmobiles), environmental factors (climate warming and less snow), changing ethics and stiffer penalties for wildlife infractions. Still the coyote is subject to much prejudice, and given deeper snow cover and higher fur prices as occurred in the winter of 2004-2005, the trend in its population, and conversely, the fox's, can be reversed.

Dedicated to the memory of Wayne C. Harris (1951 - 2002) and J. Stan Rowe (1919 - 2004).

1. FINLEY, J.K. 1996. The red fox invasion and other changes in wildlife populations in west-central Saskatchewan since the 1960s. Blue Jay 54 : 206-210.

2. FINLEY, J.K. 2005. The fox that stole the apex of Palliser's Triangle. Blue Jay 63(3): 135138.
3. FINLEY, J.K. and K.B. FINLEY. 2002. Human habitation enhances species diversity: trends over three decades of CBC's at the apex of Palliser's Triangle. Blue Jay 60: 192-198.

4. HARRIS, W.C. 2002. Saskatchewan Christmas mammal count -2001 . Blue Jay $60: 38-48$.

5. HARRIS, W.C. 1975. Saskatchewan Christmas mammal count - 1974. Blue Jay.

6. HOUSTON, C.S. 2003. In memoriam : Wayne C. Harris, 1951 - 2002. Blue Jay 61: 61- 63.

7. KAMLER, J.F. and W.B. BALLARD. 2002. A review of native and nonnative red foxes in North America. Wildlife Society Bulletin $30:$ 370-379.

8. NATURE SASKATCHEWAN. 1998. Spring Meet 1997 - Resolution \#1: Great Plains Coyote. Response from SERM. Nature Views 1998

9. ROWE, J.S. 1990. Home Place: Essays on Ecology. NeWest Publishers, Edmonton.

10. SARGEANT, A.B., ALLEN, S.H. and J.O. HASTINGS. 1987. Spatial relations between sympatric coyotes and red foxes in North Dakota. Journal of Wildlife Management 51(2) 285- 293.

11. SMITH, A.R. and R.E. JOHANSON. 62nd annual Christmas bird count -2003 . Blue Jay 62: 2-23.

12. STEWART, N.M. 1972. Coyote management in Saskatchewan. Blue Jay 30(3): 138-145

13. VOIGHT, D.R. and B.D. EARLE. 1983. Avoidance of coyotes by red fox families. Journal of Wildife Management 47 (3): 852-857.

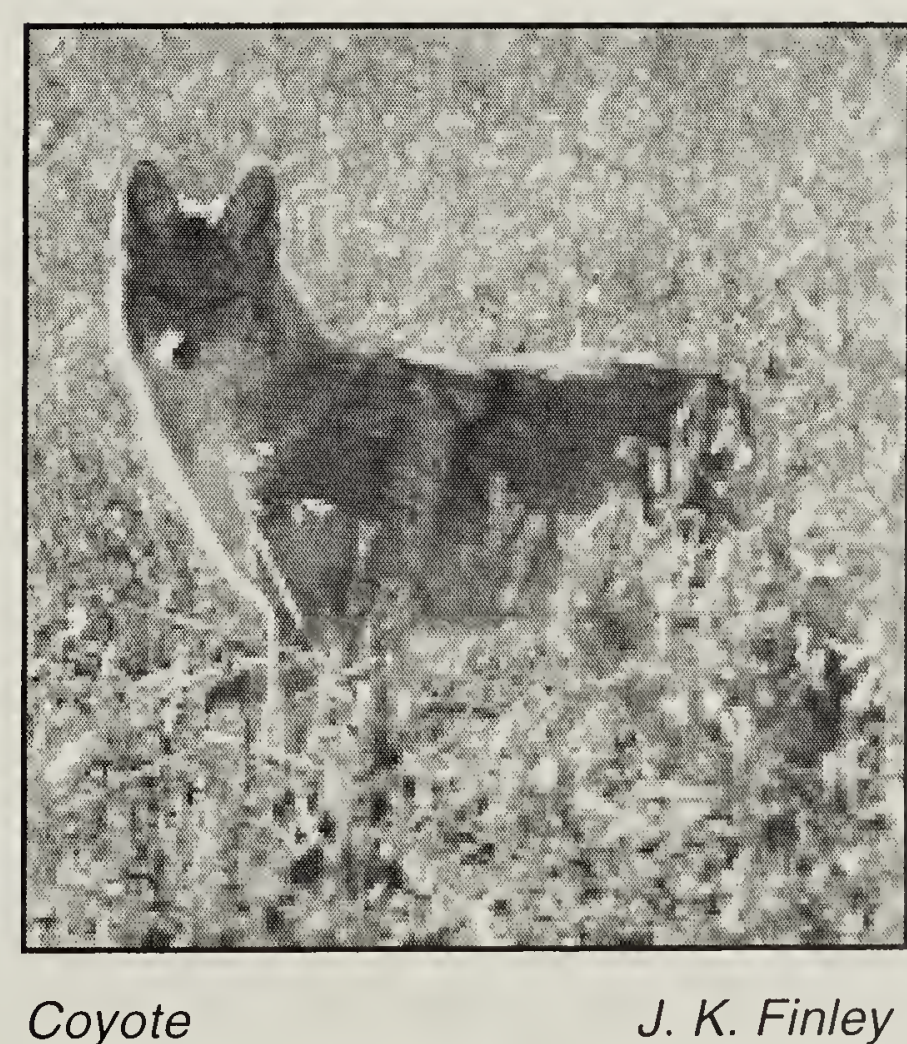

